\title{
PENDIRIAN MULTIFINANCE SYARIAH (AHD MULTIFINANCE) SEBAGAI UPAYA PENINGKATAN PEMBIAYAAN DENGAN SKEMA SYARIAH (TELAAH ASPEK KEUANGAN)
}

\author{
Wisnu Julianto ${ }^{1}$, Krisno Septyan ${ }^{2}$ \\ ${ }^{1,2}$ Universitas Pembangunan Nasional Veteran Jakarta, Email: antoacid@gmail.com \\ ${ }^{2}$ Universitas Pembangunan Nasional Veteran Jakarta, Email: krisno.septyan@ upnvj.ac.id
}

\begin{abstract}
ABSTRAK
Penelitian ini membahas mengenai perencanaan bisnis (business plan) perusahaan pembiayaan (multifinance) yang berlandaskan prinsip syariah dalam penerapan bisnisnya, khususnya mengenai perencanaan keuangan. Untuk menilai kelayakan dari bisnis ini disusun proyeksi pendapatan, biaya beban, arus kas dan neraca untuk lima tahun kedepan. Pengujian kelayakan bisnis ini juga didukung dengan metode Net Present Value (NPV), Internal Rate of Return (IRR), Profitability Index (PI), Discounted Payback Period (DPP) dan Sensitivity Analysis.
\end{abstract}

Kata kunci: Multifinance; Keuangan; Syariah.

\begin{abstract}
This research's describes the business plan of multifinance company that implements syariah principles in its business transactions, specifically about the financial planning. Projections of revenues, cost expense, cash flow and balance sheet for the five years ahead are made to analyze the feasibility of the business. The feasibility analysis will also be supported by the calculation using Net Present Value (NPV), Internal Rate of Return (IRR), Profitability Index (PI), Discounted Payback Period (DPP) and Sensitivity Analysis.
\end{abstract}

Keywords: Business Plan; Multifinance; Islamic Finance; Sharia.

\section{PENDAHULUAN}

Ekonomi kapitalisme terbukti tidak sesuai dengan harkat hidup manusia lagi karena nilai uang yang begitu kental (materalistis) yang menimbulkan nilai baru dalam dunia tersebut yaitu keberpihakan (egoistis). Perkembangan ekonomi dunia menunjukkan kehancuran akibat terlalu kuatnya sistem ekonomi ini, namun system ini menjadi dominan di Indonesia yang penduduknya mayoritas muslim. Kegelisahan ini yang mendorong peneliti untuk mencoba mencari cara bagaimana meningkatkan kegiatan ekonomi sesuai ajaran agama Islam yang dipercaya lebih menentramkan. Pendekatan yang dipakai nampaknya tidak dapat hanya secara dogmatis, namun harus secara nyata menunjukkan kepada para pelaku kegiatan ekonomi tentang keunggulan dan manfaat mengikuti syariah dalam berusaha. Khusus dalam sektor usaha pembiayaan, para peminjam harus mendapat pemahaman yang jelas bahwa ada manfaat yang lebih besar bila dibandingkan dengan skema kapitalis. Dari segi pemodal, imbal hasil yang cukup tinggi bila menggunakan akad syariah akan menarik minat mereka untuk melakukan investasi yang signifikan. Penelitian ini membahas tentang upaya yang telah dilakukan 
peneliti untuk menawarkan skema usaha pembiayaan secara syariah kepada pemodal. Alternatif pendanaan bagi pengusaha yang menginginkan skema syariah dapat dipenuhi oleh lembaga pembiayaan non-bank, khususnya multifinance. Hal ini mengingat aturan multifinance lebih fleksibel, tidak sangat ketat seperti peraturan perbankan di Indonesia. Selain itu syarat minimal modal awal pendirian sebuah multifinance lebih murah yaitu sebesar Rp. 100 milyar (Pasal 15 PMK 84/2006) dibandingakan pendirian sebuah bank yang minimal modal awalnya jauh lebih besar dan Tingkat persaingan di bisnis multifinance syariah yang belum ketat dimana pada tahun 2010, hanya ada sebelas perusahaan multifinance syariah dibandingkan total 192 perusahaan multifinance yang ada saat ini dan juga market share multifinance syariah pada tahun 2010 baru mencapai 1,14\% atau baru Rp 2.149 Milyar. Belum lagi pangsa pasar syariah di Indonesia yang masih besar dimana berdasarkan data BKKBN, penduduk Indonesia 2011 diperkirakan sebanyak 241 juta orang diasumsikan $85 \%$ nya adalah muslim.

Perkembangan ekonomi Indonesia yang sangat baik sehingga terciptanya pangsa pasar yang cukup luas untuk kredit kendaraan bermotor, ini dapat terlihat penjualan kendaraan bermotor mengalami pertumbuhan dari tahun ke tahun. Selain isu tersebut tersebut terdapat pula hal-hal lain seperti penyadaran masyarakat tenang pentingnya lembaga keuangan berbasis syariah, informasi mengenai sistem akad-akad syariah, sampai kepada lembaga keuangan syariah dalam hal ini multifinance syariah tidak hanya untuk orang Islam saja, tetapi untuk seluruh masyarakat apapun agama yang mereka anut. Sehingga dapat (1) menunjukkan besarnya potensi lembaga keuangan syariah non bank khususnya usaha multifinance syariah. (2) Memberikan gambaran strategi bisnis dan pengelolaan bisnis model dalam usaha multifinance syariah. (3) Memudahkan pelaku usaha dalam mencari informasi dan pembelajaran tentang bagaimana pengelolan usaha multifinance syariah.

\section{METODE PENELITIAN}

Adapun metode penelitian yang dilakukan dalam usaha ini berdasarkan model yang dibuat oleh David (2003).

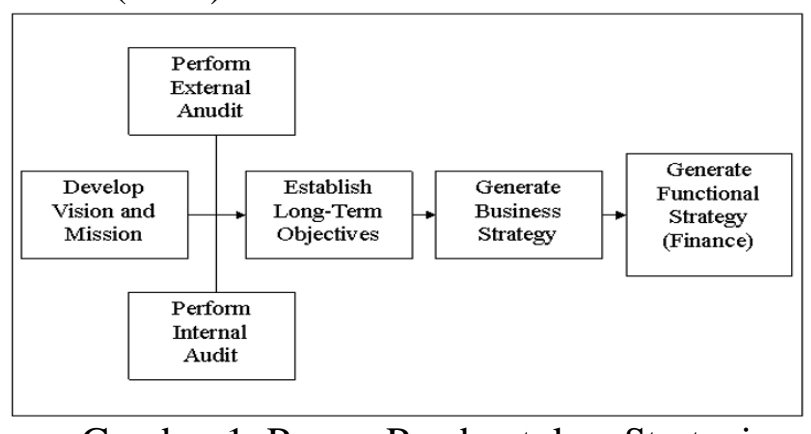

Gambar 1. Proses Pembentukan Strategi Sumber: David (2003), diolah oleh penulis 
Dari gambar 1 di atas urutan penulisan rencana bisnis adalah membentuk visi dan misi perusahaan. Setelah itu penelitian secara internal maupun eksternal. Berdasarkan hal-hal tersebut akan menghasilkan beberapa strategi yang akan diimplementasikan.

\section{Business Plan}

Business Plan merupakan penjelasan tertulis dari masa depan sebuah bisnis, yaitu sebuah dokumen yang menceritakan apa yang direncanakan untuk dilakukan, dan bagaimana merencanakan untuk melakukannya (Bangs, 2005). Bisnis yang baik umumnya dimulai dengan perencanaan yang baik, mulai dari rencana model bisnis, analisis pasar dan strategi pemasaran, strategi pendanaan, manajemen risiko, rencana operasional dan sumber daya manusia, sampai dengan analisis keuangan. Semua harus dilakukan dengan matang, seperti kalimat yang dikutip dari Harvey Mackay, "if you fail to plan, then you plan to fail". Diterjemahkan secara bebas berarti, jika anda gagal dalam merencanakan, maka anda merencanakan kegagalan anda.Business Plan yang baik harus dapat menggambarkan secara rinci dari bisnis yang akan dijalankan. Hal itu diperlukan karena akan ada dua pihak yang membutuhkan business plan ini, yaitu: pertama. pihak manajemen sebagai pegangan dalam menentukan tujuan bisnis dan dan menjalankan bisnis tersebut. Kedua, pihak investor, sebagai alat bantu penentuan keputusan penanaman modal, berdasarkan hal-hal yang tercantum dalam business plan tersebut.

\section{Tujuan Perusahaan}

Tujuan adalah keadaan yang diinginkan di masa depan, yang diupayakan oleh perusahaan untuk diraih (Daft, Marcic, 2006). Sebuah perusahaan tentu memiliki tujuan yang hendak dicapai. Tujuan inilah yang kemudian menjadi motivasi seluruh elemen di perusahaan tersebut dalam menjalankan aktivitasnya. Sedangkan rencana merupakan sebuah cetak biru untuk meraih tujuan dan menspesifikan alokasi sumber daya yang dibutuhkan, jadwal, tugas dan tindakan lainnya (Daft, Macic, 2006). Bagan berikut mengilustrasikan tingkatan dari tujuan dan perencanaan dalam perusahaan:

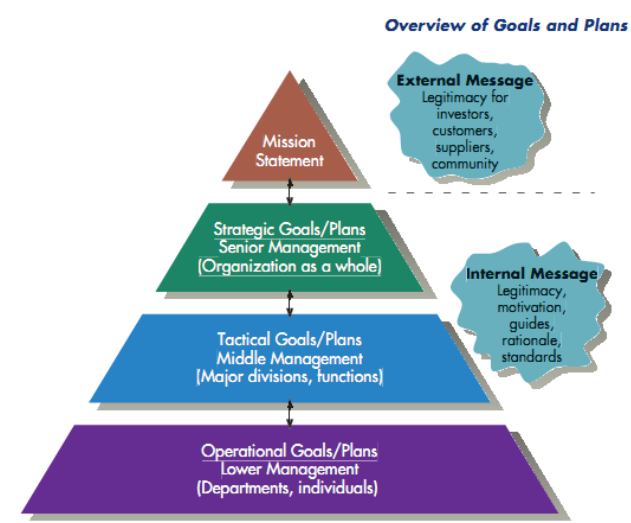

Gambar 2. Level of Goal Plans

Sumber: Daft, Macic. (2006) Understanding Management 5e, Thomson South-Western, p159 
Pada gambar 2 di atas dapat dilihat bahwa Misi merupakan dasar dari tujuan dan rencana level strategis, yang kemudian membentuk ke level taktikal dan operasional. Berbagai level manajemen yang berbeda akan bertanggung jawab untuk menjalankan tujuan dan rencana perusahaan tersebut. Menurut Peter Drucker dalam Eight Content Areas in Developing Goals, salah satu kekeliruan dalam mengatur perusahaan adalah hanya fokus pada satu tujuan pokok, seharusnya perusahaan berusaha untuk meraih beberapa tujuan. Menurut Peter Drucker, ada delapan ruang lingkup yang umumnya digunakan untuk menentukan tujuan perusahaan:

1. Market standing, yaitu posisi relatif perusahaan dibandingkan dengan para pesaingnya.

2. Innovation, yaitu berbagai perubahan atau pengembangan yang dilakukan perusahaan untuk memperbaiki metode bisnis dan produknya.

3. Productivity, yaitu tingkat produksi barang atau jasa perusahaan yang dibandingkan dengan sumber daya yang digunakan dalam proses produksi tersebut.

4. Resources levels, yaitu jumlah relatif dari berbagai sumber daya yang disimpan oleh perusahaan seperti persediaan, peralatan, serta kas.

5. Profitability, yaitu kemampuan suatu perusahaan untuk menghasilkan pendapatan yang menutupi biaya-biaya yang dikeluarkan untuk menghasilkan pendapatan tersebut.

6. Manager performance and attitude, yaitu kualitas kinerja pegawai tingkat manajerial dan tingkat perkembangan manajer secara perorangan.

7. Worker performance and attitude, yaitu kualitas kinerja pegawai non manajemen dan bagaimana pekerja tersebut memaknai pekerjaannya.

8. Social responsibility, yaitu kewajiban perusahaan untuk membantu memperbaiki kesejahteraan masyarakat.

\section{Lingkungan Internal Perusahaan}

Faktor lingkungan internal perusahaan meliputi segala aspek manajemen fungsional seperti pemasaran, keuangan, operasi, sumber daya manusia, penelitian dan pengembangan, sistem informasi manajemen, dan budaya perusahaan (Hitt, et al, 2001). Dengan mengidentifikasi lingkungan internal ini, perusahaan dapat mengetahui profil keunggulan strategi perusahaan yang dimiliki. Untuk menganalisis kondisi internal perusahaan dapat dilakukan dengan kerangka konsep rantai nilai (value chain). Menurut Porter, bisnis suatu perusahaan dengan sangat baik dapat digambarkan melalui konsep rantai nilai (David, 2006), dimana pendapatan total dikurangi biaya total dan semua aktivitas yang dijalankan untuk mengembangkan dan memasarkan suatu produk atau jasa menghasilkan. Suatu perusahaan akan mendapatkan keuntungan selama total pendapatan melebihi total biaya yang muncul untuk menciptakan dan mengantarkan produk dan jasa. 


\section{Lingkungan Industri}

Industri merupakan grup atau kumpulan dari perusahaan yang memproduksi produk yang saling mensubsitusi (Ireland,Hoskisson,Hitt, 2007). Lingkungan industri merupakan sekumpulan faktor yang secara langsung mempengaruhi sebuah perusahaan dan tindakan serta respon kompetitifnya: ancaman pendatang baru, kekuatan suppliers, kekuatan pembeli, ancaman produk substitusi dan intensitas persaingan diantara kompetitor (Hitt, Ireland, Hoskisson, 2009). Hal itu sejalan dengan model Five Forces Porter seperti gambar dibawah ini:

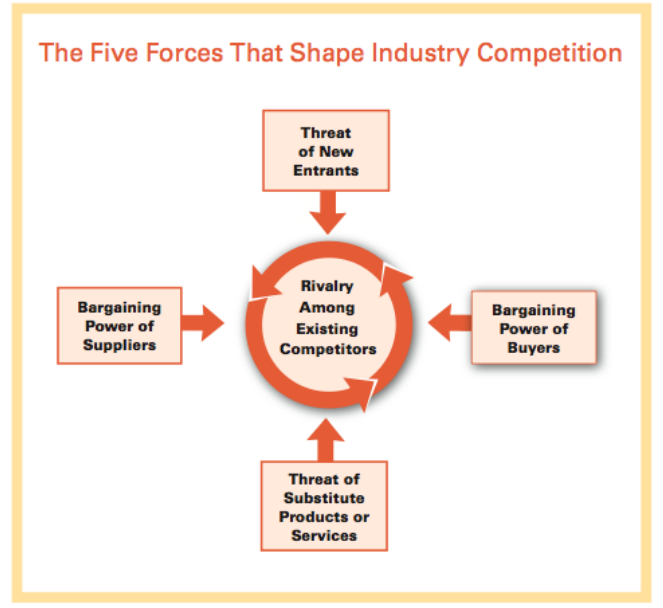

Gambar 3. Five Forces Porter

Sumber: Porter, M.E. (2008) The Five Competitive Forces That Shape Strategy, Harvard Business

\section{Murabahah} Review, January 2008.

Sesuai dengan Fatwa Dewan Syari'ah Nasional No: 04/DSN-MUI/IV/2000, murabahah adalah menjual suatu barang dengan menegaskan harga belinya kepada pembeli dan pembeli membayarnya dengan harga yang lebih sebagai laba.

\section{Musyarakah}

Berdasarkan Fatwa Dewan Syari'ah Nasional No: 08/DSN-MUI/IV/2000, musyarakah adalah akad kerjasama antara dua pihak atau lebih untuk suatu usaha tertentu, dimana masing-masing pihak memberikan kontribusi dana dengan ketentuan bahwa keuntungan dan risiko akan ditanggung bersama sesuai dengan kesepakatan.

\section{Mudharabah}

Berdasarkan Fatwa Dewan Syari'ah Nasional No: 07/DSN-MUI/IV/2000, mudharabah adalah akad kerjasama suatu usaha antara dua pihak di mana pihak pertama (malik, shahib al-mal, LKS) menyediakan seluruh modal, sedang pihak kedua ('amil, mudharib, nasabah) bertindak selaku pengelola, dan keuntungan usaha dibagai diantara mereka sesuai kesepakatan yang dituangkan dalam kotrak. 


\section{Ijarah}

Berdasarkan fatwa Dewan Syari'ah Nasional No: 09/DSN-MUI/IV/2000, ijarah adalah akad pemindahan hak guna (manfaat) atas suatu barang dalam waktu tertentu dengan pembayaran sewa (ujrah), tanpa diikuti dengan pemindahan kepemilikan barang itu sendiri.

\section{Ju'alah}

Berdasarkan fatwa Dewan Syari'ah Nasional No: 62/DSB-MUI/XII/2007, beberapa ketentuan umum dari akad Ju'alah adalah sebagai berikut:

1. Ju'alah adalah janji atau komitmen (iltizam) untuk memberikan imbalan (reward/I'wadh//ju'l) tertentu atas pencapaian hasil (natijah) yang ditentukan dari suatu pekerjaan.

2. Ja'il adalah pihak yang berjanji akan memberikan imbalan tertentu atas pencapaian hasil pekerjaan (natijah) yang ditentukan.

3. Maj'ul lah adalah pihak yang melaksanakan Ju'alah.

\section{Al-Qardh}

Berdasarkan fatwa Dewan Syari'ah Nasional No: 19/DSN-MUI/IV/2001, LKS dapat juga melakukan penyaluran dana melalui prinsip Al-Qardh, yaitu suatu akad pinjaman kepada nasabah dengan ketentuan bahwa nasabah wajib mengembalikan dana yang diterimanya kepada LKS pada waktu yang telah disepakati oleh LKS dan nasabah.

\section{Manajemen Risiko}

Risiko merupakan suatu kejadian potensial, baik yang dapat diperkirakan (anticipated), maupun yang tidak dapat diperkirakan (unanticipated) yang berdampak negatif terhadap pendapatan dan permodalan perusahaan (Karim, 2004). Risiko-risiko tersebut tidak dapat dihindari, tetapi dapat dikelola dan dikendalikan. Oleh karena itu diperlukan serangkaian prosedur dan metodologi yang dapat digunakan untuk mengidentifikasi, mengukur, memantau, dan mengendalikan risiko yang timbul dari kegiatan usaha, rangkaian prosedur dan metodologi ini dinamakan manajemen risiko (Karim, 2004).

\section{Key Success Factor}

Key success factor yang diperkenalkan oleh Kenichi Ohmae merupakan suatu konsep yang mengidentifikasikan faktor-faktor apa saja yang dibutuhkan perusahaan agar berhasil dalam suatu industri (Ohmae, 2005). Menurut Ohmae, pendekatannya untuk menidentifikasi key success factor itu lugas dan masuk akal. Ohmae juga mengenalkan model 3C's, yaitu sebuah model bisnis yang memaparkan tiga hal yang harus menjadi fokus perusahaan untuk meraih sukses, antara lain sebagai berikut: 


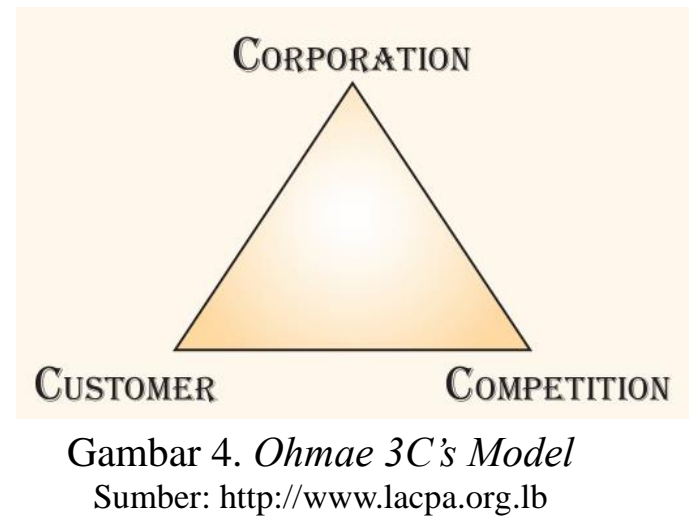

1. The ccrporation. Perusahaan membutuhkan strategi untuk memaksimalkan kekuatan perusahaan dalam persaingan pada area-area penting untuk meraih sukses dalam industri. Oleh karena itu perusahaan harus selektif, dapat mengambil keputusan untuk memproduksi atau membeli, serta mencapai cost-effectiveness.

2. The customer. Perusahaan harus mengetahui siapa yang menjadi pelanggannya, umumnya dilakukan dengan melakukan segmentasi. Segmentasi dapat dilakukan berdasarkan tujuan pelanggan dalam memakai produk perusahaan, jangkauan pelanggan, dan dalam pasar yang kompetitif, terkadang harus dilakukan segmentasi ulang pelanggan perusahaan.

3. The competitor. Perusahaan perlu mengetahui siapa saja yang menjadi kompetitornya. Faktor apa saja yang utama dan mempengaruhi persaingan. Hal apa yang dibutuhkan untuk menguasai pasar. Resource apa yang tidak dimiliki oleh pesaing, dan apa yang tidak dimiliki oleh perusahaan.

\section{Perencanaan Keuangan}

Menurut Murdifin Haming dan Salim Basalamah, 2003, untuk menilai kelayakan suatu proyek untuk dibiayai perlu dilakukan kajian terhadap aspek keuangan yang mencakup:

1. Kajian jumlah dana proyek yang dibutuhkan terdiri dari investasi awal maupun untuk kebutuhan modal kerja.

2. Kajian sumber dana, mencakup perhitungan biaya atas modal yang direncanakan ditarik dan struktur modal dari pembiayaan proyek.

3. Proyeksi arus kas mencakup rincian prospek arus kas masuk dan keluar, untuk dijadikan acuan penilaian analisis kelayakan keuangan dengan berbagai metode yang lazim, yaitu payback method, net present value (NPV), profitability index (PI) dan internal rate of return (IRR).

4. Penyusunan laporan keuangan proforma, dilengkapi dengan analisis sumber dan penggunaan dana serta analisis titik impas (break even analysis atau BEA). 
5. Kajian pengaruh indikator makro ekonomi terhadap keuangan proyek, terutama proyeksi arus kas.

\section{Perhitungan Kebutuhan Dana Investasi}

Terkait jenis penggunaannya, dana dapat dibedakan menjadi dana investasi awal atau initial investment dan dana modal kerja. Initial investment adalah investasi yang diperlukan untuk mengadakan barang modal, tanah lokasi, pengadaan alat-alat kantor dan jasa-jasa umum serta sarana pendukung lainnya. Sedangkan modal kerja adalah dana yang diperlukan untuk membiayai aktivitas operasi setelah memasuki fase operasi komersial. Bila dihubungkan dengan pengeluaran, maka sebuah proyek memerlukan dua macam pengeluaran, yaitu: pertama. pengeluaran modal (capital expenditure), yaitu pengeluaran untuk initial investment, seperti biaya untuk bangunan, instalasi jasa umum, mesin kantor dan mebel, biaya perizinan dan kendaran yang harus disediakan. Kedua, pengeluaran operasional untuk memperoleh pendapatan (operating atau revenue expenditure), seperti biaya gaji, pemasaran, biaya tunai lainnya dengan melakukan perhitungan terhadpa target volume dan nilai penjualan per tahun.

\section{Penilaian Penanaman Modal dalam Proyek Investasi}

Penilaian penanaman modal dalam proyek investasi dilakukan untuk dapat meyakini apakah suatu proyek investasi secara teknis dan ekonomis layak sehingga dapat menguntungkan secara finansial (Karim, 2004). Penilaian kelayakan investasi dari suatu proyek dilakukan dengan cara atau berdasarkan:

1. Analisis break even. Tujuan utama dari analisis break even adalah untuk menentukan tingkat produksi dan harga terendah, pada tingkat mana proyek dapat beroperasi tanpa membahayakan kelangsungan hidupnya (laba atau rugi = nihil).

2. Analisis perbandingan penanaman modal dalam berbagai alternatif proyek (capital project comparisons). Dilakukan perbandingan potensi penghasilan suatu proyek dengan proyek lainnya, dengan tolak ukur total profit, average profit, payback period dan discounted cash flow (present value proceeds dan present value capital outlay).

3. Analisis rasio keuangan. Analisis rasio keuangan yang dapat digunakan dalam penilaian penanaman modal pada proyek investasi terkait penyusunan skema pembiayaan AHD multifinance adalah:

a. Financial viability perusahaan, atas ukuran: analisis cash flow dan assets management.

b. Profitabilitas perusahaan, atas ukuran: profit margin, return on investment ratios, earning fluctuations dan industry comparisons.

c. Proyeksi atas performa, atas ukuran : proyeksi pendapatan, cash flow, kondisi financial dan model performa. 
4. Analisis risiko. Terdiri dari analisis sensitivitas dan probabilitas, yaitu:

a. Analisis sensitivitas, merupakan penilaian risiko yang terjadi diluar perhitungan sebagai contoh : cost over run dampak dari inflasi yang belum diperhitungkannya komponen tertentu dalam capital cost.

b. Analisis probabilitas, merupakan penilaian yang didasarkan pada perhitungann statistik bahwa setiap proyek memiliki unsur probabilitas yang menunjukkan prediksi mengenai risiko dari suatu proyek. Dalam hal pembiayaan investasi yang sulit untuk dilakukan analisis probabilitas, maka dapat dilakukan analisis sensitivitas.

5. Degree of Operating Leverage (DOL), merupakan pengukuran pada tingkat penjualan tertentu, persentase perubahan volume penjualan akan mempengaruhi keuntungan. Cara perhitungan DOL:

$$
\begin{aligned}
& \mathrm{DOL}=\frac{\% \text { change in Operating Income }}{\% \text { change in Sales }} \\
& \mathrm{DOL}=\frac{\text { Total Contribution }}{\text { Operating Income }}=\frac{\text { Total Contribution }}{\text { Total Contribution }- \text { Fixed Costs }}=\frac{(\mathrm{P}-\mathrm{V}) \times \mathrm{X}}{(\mathrm{P}-\mathrm{V}) \times \mathrm{X}-\mathrm{FC}} \\
& \mathrm{DOL}=\frac{\text { Contribution Margin Ratio }}{\text { Operating Margin }}
\end{aligned}
$$

Sumber: Brigham, Eugene (1995) Fundamentals of Financial Management

Contribution margin adalah pengukuran dari operating leverage, semakin tinggi nilai contribution margin maka semakin cepat keuntungan meningkat dari tingkat penjualan tertentu.

\section{ANALISIS PASAR DAN STRATEGI BISNIS}

\section{Remote Environment}

Remote environment terkait dengan hal-hal berikut ini:

1. Ekonomi

Di tengah ketidakseimbangan pemulihan ekonomi global, kinerja perekonomian domestik selama tahun 2010 terus mengalami perbaikan. Pertumbuhan ekonomi domestik selama tahun laporan mencapai $6,1 \%$, lebih tinggi dari pertumbuhan tahun 2009 yang hanya mencapai 4,6\%. Peningkatan tersebut didukung oleh sumber pertumbuhan yang semakin berimbang, sebagaimana tercermin pada peran investasi dan ekspor yang meningkat. Peningkatan investasi pada tahun 2010 ditandai dengan semakin tingginya peranan investasi yang sifatnya menambah kapasitas ekonomi. Sementara itu, perbaikan kinerja ekspor juga diikuti oleh semakin terdiversifikasinya komoditas dan negara tujuan ekspor, yang tercermin pada membaiknya kinerja sektor-sektor yang menghasilkan komoditas yang diperdagangkan secara 
internasional (tradable sector), khususnya industri pengolahan. (Bank Indonesia, Laporan Perekonomian Tahun 2010, April 2011). Inflasi pada bulan Oktober 2011 Sebesar 4,42\% turun sebesar 0,19\% dari bulan sebelumnya yaitu pada bulan September sebesar 4,61\%. Adapun inflasi tahunan pada tahun 2011 sampai pada bulan Oktober yaitu rata-rata sebesar 5,66\%.

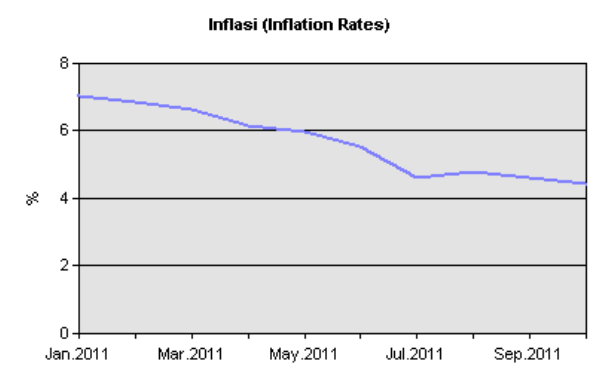

Sumber: Bank Indonesia

Gambar 5. Tingkat Inflasi Januari-Oktober 2011

Produk Domestik Bruto (PDB) pada tahun 2010 menurut asumsi dari Departemen Keuangan sekitar 6253,8 triliun rupiah, naik sekitar 11,4 persen dari tahun sebelumnya yang mencapai 5613,4 triliun rupiah (Badan Pusat Statistik, 2011) sehingga ini mengindikasikan gairah industri di negara ini meningkat. Oleh karena itu diharapkan daya beli masyarakatnya pun meningkat. Pertumbuhan ekonomi di Indonesia yang cenderung positif ditengah krisis ekonomi yang melanda sebagian eropa mengindikasikan daya beli dan pendapatan masyarakat sangat baik.

2. Sosial

Kondisi sosial di Indonesia selama kurun waktu tahun 2010 - 2011 cukup stabil, meskipun terjadi beberapa konflik di beberapa daerah, namun skalanya hanya lokal dan tidak sampai mengganggu stabilitas nasional. Hal itu tentunya sangat berpengaruh pada iklim investasi di Indonesia, ditunjukkan adanya tren positif selama tahun 2010 dan 2011.

3. Politik

Selama tahun 2010 dan 2011, kondisi politik pun menunjukkan kondisi yang stabil. Pemilu yang berjalan dengan sukses dan aman di tahun 2009, serta kemenangan mutlak yang diraih oleh Presiden Susilo Bambang Yudhoyono, turut mendorong stabilitas politik dalam kurun waktu tersebut. Memang terjadi sedikit gejolak-gejolak politik terutama pada koalisi partai-partai yang berkuasa, dimana beberapa kali ada ancaman untuk keluar dari koalisi. Namun ancaman tersebut mereda seiring lobi-lobi politik yang dilakukan oleh elit parpol tersebut. Sedikit masalah politik yang berpotensi menggangu iklim investasi adalah masalah Pemilihan Kepala Daerah (Pilkada) yang tidak jarang berujung sengketa, atau adanya ketidakpastian peraturan daerah yang cenderung berubah bergantung 
pada kepala daerah yang terpilih. Hal ini tentu saja membuat khawatir investor, oleh karena itu investasi umum dilakukan di daerah-daerah yang cenderung stabil dan mulus dalam pergantian kepala daerahnya.

4. Teknologi

Perkembangan teknologi dunia yang terjadi dalam kurun waktu 2010 2011 sangat pesat, terutama perangkat-perangkat komputasi dan telekomunikasi personal. Tren yang terjadi adalah masyarakat dapat mengakses informasi dengan cepat kapanpun dan di manapun. Indonesia sebagai salah satu negara dengan penduduk terbesar di dunia, menjadi pasar yang strategis bagi penjualan produk-produk tersebut. Sempat timbul sebuah polemik mengenai izin operasi Blackberry di Indonesia, terkait dengan konten-konten terlarang yang masih dapat diakses melalui perangkat tersebut, namun akhirnya pihak Research in Motion (produsen Blackberry) mau mengikuti ketentuan dari Pemerintah RI.

\section{Analisis Pasar}

Analisis pasar terkait dengan hal-hal berikut ini:

1. Peluang (opportunity). Peluang industri keuangan syariah yang masih terbuka lebar di Indonesia, terlebih memperhitungkan posisi Indonesia sebagai Negara dengan penduduk muslim terbesar di dunia. Kebutuhan akan kendaraan baik kendaraan niaga maupun non produktif yang terus meningkat setiap tahunnya, turut membuat industri ini menjadi menarik.

2. Ancaman (threats). Sebagai perusahaan multifinance syariah yang baru, ancaman muncul dari multifinance syariah yang sudah ada, serta dari perbankan syariah yang menawarkan produk sejenis kepada masyarakat.

\section{Analisis Internal}

Analisis internal terkait dengan hal-hal berikut ini:

1. Sumber daya. Didukung dengan sumber daya yang cukup, baik sumber daya manusia maupun finansial, perusahaan ini diyakini akan mampu bersaing dengan multifinance syariah yang sudah ada.

2. Kekuatan (strenght). Perusahaan ini memiliki kekuatan dari managemen yang akan mengelola perusahaan ini. Dukungan modal yang kuat dan relasi dengan dealer-dealer akan menjadi kekuatan tersendiri dari perusahaan ini, selain dari program-program marketing yang dipersiapkan untuk menarik pelanggan.

3. Kelemahan (weakness). Sebagai perusahaan yang baru, tentunya kelemahan dari perusahaan ini adalah mengenai reputasi perusahaan dan jumlah jaringan. Kelemahan ini akan berusaha diminimalisir dengan program marketing untuk meningkatkan reputasi perusahaan, baik bagi dealer maupun masyarakat. Sedangkan untuk jumlah jaringan, kami fokus untuk menguatkan line bisnis di 
Jabodetabek, kemudian secara bertahap akan melebarkan sayap perusahaan ke seluruh Indonesia.

\section{Strategi}

Definisi dari strategi adalah suatu kumpulan kegiatan-kegiatan yang saling terkait yang digunakan untuk meningkatkan performa perusahaan (Hill \& Jones, 1989). Strategi juga merupakan suatu kegiatan pencarian secara sistematis mengenai rencana dari suatu aksi yang bertujuan untuk mengembangkan keunggulan kompetitif (Henderson, 1989). Strategi tersebut dimulai dari pemahaman akan lingkungan tempat suatu perusahaan itu dan apa yang benar-benar dimiliki oleh perusahaan tersebut pada saat tertentu. Perusahaan yang bergerak disatu bidang tertentu dan mempunyai struktur organisasi yang kecil lebih tepat apabila menggunakan business level strategy dibandingkan dengan corporate level strategy. Strategi tingkat bisnis menekankan pada bagaimana suatu perusahaan berkompetisi dalam suatu industri ataupun pasar yang lebih spesifik (Grant, 2004). Penerapan business level strategy pada AHD Multifinance dirasakan cocok, mengingat struktur dan kegiatan perusahaan yang tidak kompleks dan hanya pada satu sektor saja yaitu pembiayaan.

\section{Perumusan Strategi}

Ada berbagai metode untuk menyusun strategi bisnis. Dalam rangka pemilihan strategi bisnis, perlunya dilakukan analisis terkait faktor-faktor eksternal dan internal. Untuk pendirian AHD Multifinance Syariah metode yang digunakan adalah External Factors Evaluation (EFE) dan Internal Factors Evaluation (IFE) (David, 2003).

\section{External Factor Evaluation (EFE)}

Proses penyusunan EFE dilakukan dengan identifikasi seluruh faktor diluar perusahaan yang mungkin mempengaruhi jalannya perusahaan dilingkungan dimana perusahaan tersebut beroperasi. Faktor-faktor yang berhasil diperoleh kemudian dipilah-pilah untuk mengetahui mana yang paling mungkin mempengaruhi. Pengelompokan faktor dilakukan menurut sifatnya yang mendukung atau menghambat jalannya perusahaan. Faktor-faktor peluang (opportunity) dan ancaman (threat) yang dianggap memberikan kontribusi dengan usaha ini dimuat pada suatu daftar, kemudian diberikan bobot (weight). Bobot menunjukkan seberapa penting dan signifikan faktor tersebut mempengaruhi usaha. Jumlah bobot dari semua faktor eksternal adalah satu, yang didistribusikan ke masing-masing faktor. 
Tabel 1. External Factors Evaluation (EFE) Lembaga Pembiayaan Syariah

\begin{tabular}{|c|c|c|c|c|}
\hline \multicolumn{5}{|c|}{ External Factors Evaluation (EFE) } \\
\hline \multicolumn{2}{|c|}{ Opportunities } & \multirow{2}{*}{$\frac{\text { Weight }}{0.02}$} & \multirow{2}{*}{$\frac{\text { Rating }}{1}$} & \multirow{2}{*}{$\frac{\text { Weighted Score }}{0.02}$} \\
\hline 1 & $\begin{array}{l}\text { Suku bunga BI cenderung } \\
\text { stabil }\end{array}$ & & & \\
\hline 2 & $\begin{array}{l}\text { Rating investasi Negara } \\
\text { RI meningkat }\end{array}$ & 0.02 & 1 & 0.02 \\
\hline 3 & $\begin{array}{l}\text { Proses kredit lama dan } \\
\text { berbelit }\end{array}$ & 0.02 & 2 & 0.04 \\
\hline 4 & $\begin{array}{l}\text { Tersedianya } \\
\text { berkualitas }\end{array}$ & 0.02 & 2 & 0.04 \\
\hline 5 & $\begin{array}{l}\text { Peraturan Bank Indonesia } \\
\text { yang ketat }\end{array}$ & 0.05 & 2 & 0.1 \\
\hline 6 & $\begin{array}{l}\text { Kebutuhan modal yang } \\
\text { besar }\end{array}$ & 0.06 & 3 & 0.18 \\
\hline 7 & $\begin{array}{l}\text { Demand akan pembiayaan } \\
\text { kendaraan bermotor masih } \\
\text { besar }\end{array}$ & 0.2 & 4 & 0.8 \\
\hline 8 & $\begin{array}{l}\text { Lembaga pembiayaan } \\
\text { murni syariah masih } \\
\text { sedikit }\end{array}$ & 0.06 & 2 & 0.12 \\
\hline 9 & $\begin{array}{l}\text { Kondisi pasar keuangan } \\
\text { yang likuid }\end{array}$ & 0.1 & 3 & 0.3 \\
\hline & & Weight & Rating & Weighted Score \\
\hline 1 & $\begin{array}{l}\text { Daya beli masyarakat } \\
\text { menurun }\end{array}$ & 0.05 & 2 & 0.1 \\
\hline 2 & Persaingan dengan Bank & 0.2 & 2 & 0.4 \\
\hline 3 & $\begin{array}{l}\text { Faktor politik menjelang } \\
\text { Pemilu }\end{array}$ & 0.05 & 1 & 0.05 \\
\hline 4 & Switching cost rendah & 0.05 & 3 & 0.15 \\
\hline 5 & $\begin{array}{l}\begin{array}{l}\text { Langkanya } \\
\text { syariah }\end{array} \\
\end{array}$ & 0.1 & 2 & 0.2 \\
\hline & veight & 1.0 & & 2.52 \\
\hline
\end{tabular}

Dari hasil pembobotan atas faktor-faktor eksternal di atas, bisa dilihat bahwa terdapat dua faktor penting dalam pendirian multifinance ini yaitu demand untuk pembiayaan yang non-bankable serta persaingan dengan Bank (0.2). Sedangkan tawaran kerjasama dari para pemilik modal dan langkanya SDM mahir syariah memiliki tingkat bobot tinggi kedua (0.1)

\section{Internal Factor Evaluation (IFE)}

Jalannya perusahaan juga tergantung dari apa yang sudah dimiliki oleh perusahaan yang merupakan faktor internal. Setelah analisis ancaman dan peluang, maka perlu juga dilakukan analisis terhadap kemampuan dari internal perusahaan. Dibawah ini merupakan evaluasi faktor-faktor internal perusahaan. 
Tabel 2. Internal Factors Evaluation (IFE) Perusahaan

\begin{tabular}{|c|c|c|c|c|}
\hline \multicolumn{5}{|c|}{ Internal Factors Evaluation (EFE) } \\
\hline & unities & Weight & Rating & Weighted Score \\
\hline 1 & $\begin{array}{l}\text { Kemampuan pemimpin } \\
\text { perusahaan yang baik }\end{array}$ & 0.1 & 3 & 0.3 \\
\hline 2 & $\begin{array}{l}\text { Modal yang cukup untuk } \\
\text { membangun perusahaan }\end{array}$ & 0.1 & 3 & 0.3 \\
\hline 3 & $\begin{array}{l}\text { Pengalaman dalam operasi } \\
\text { lembaga } \\
\text { syariah }\end{array}$ & 0.15 & 4 & 0.6 \\
\hline 4 & $\begin{array}{l}\text { Memiliki hubungan yang } \\
\text { baik dengan sumber } \\
\text { pendanaan }\end{array}$ & 0.05 & 3 & 0.15 \\
\hline 5 & Lokasi & 0.15 & 4 & 0.6 \\
\hline \multicolumn{2}{|c|}{ Weakness } & Weight & Rating & Weighted Score \\
\hline 1 & $\begin{array}{l}\text { Belum terjalinnya hubungan } \\
\text { dengan agen penjual } \\
\text { kendaraan bermotor }\end{array}$ & 0.2 & 2 & 0.4 \\
\hline 2 & $\begin{array}{l}\text { Merupakan pemain baru } \\
\text { sehingga belum dikenal }\end{array}$ & 0.15 & 2 & 0.3 \\
\hline 3 & $\begin{array}{l}\text { Belum memiliki sistem } \\
\text { operasi yang handal }\end{array}$ & 0.05 & 2 & 0.1 \\
\hline 4 & $\begin{array}{l}\text { Belum memiliki sumber } \\
\text { daya manusia yang cukup }\end{array}$ & 0.1 & 2 & 0.2 \\
\hline & & 1.0 & & 2.8 \\
\hline
\end{tabular}

Berdasarkan tabel di atas, menunjukkan kekuatan yang dimiliki perusahaan adalah kehandalan dan pengalaman dari para pemilik perusahaan, yang merupakan peranan penting bagi perusahaan untuk melakukan rencana bisnis ini. Sedangkan kelemahan dari perusahaan ini adalah belum terjalinnya hubungan dengan dealer dan merupakan pemain baru sehingga belum dikenal masyarakat luas untuk menjalankan bisnis ini.

Dengan membuat analisis model EFE dan IFE ini dihasilkan suatu input mengenai hal-hal apa saya yang harus di perhatikan dan dipertimbangkan dalam penyusunan strategi bisnis. Kemudian dilakukan proses pencocokkan faktor-faktor eksternal dengan internal. Proses selanjutnya adalah pencocokan dengan menggunakan Internal External (IE) Matrix (David, 2003). Pada IE Matrix dapat dilihat kondisi dari perusahaan dan strategi yang harus dilakukan. Berdasarkan nilai EFE 2,52 dan IFE 2,80 maka pembiayaan syariah ada pada kuadran V, dengan kondisi dan strateginya adalah Hold \& Maintain (David, 2003). Dengan kondisi ini maka kondisi perusahaan dapat melangsungkan usahanya dan menggunakan strategi-strategi yang bersifat fokus dan penetrasi pasar. 


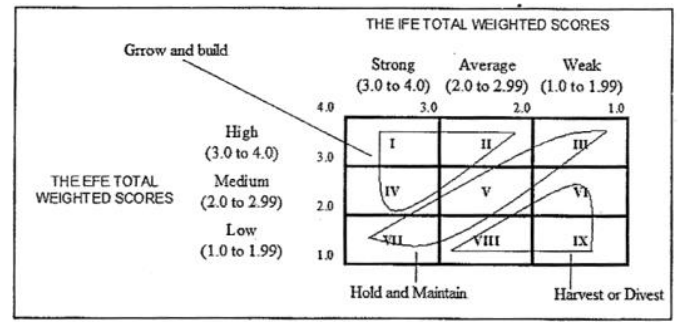

Sumber: (David, 2003) "telah diolah kembali"

Gambar 6. The Internal - External (IE) Matrix

\section{Pemilihan Strategi Bisnis}

Pemilihan strategi bisnis perusahaan lembaga pembiayaan syariah ini akan didasarkan pada hasil analisis industri yang telah dilakukan sebelumnya, bahwa kesimpulan awal adalah usaha pembiayaan syariah cukup menarik untuk dimasuki. Walaupun ketertarikan yang tinggi dari industri ini, untuk bisa memasuki dan mendirikan perusahaan yang mapan di industri ini diperlukan suatu strategi untuk menjalankan perusahaan. Strategi adalah suatu pola dasar dari tujuan saat ini dan masa depan, alokasi sumber daya, interaksi perusahaan dengan pasar, kompetitor dan faktor-faktor lain yang ada di lingkungan (Mullin, 2010). Pemilihan strategi yang akan digunakan oleh perusahaan yang akan dibentuk dengan menggunakan strategi imitasi (Lieberman, 2006). Hasil SWOT di atas merupakan strategi yang digunakan oleh para pelaku sektor pembiayaan saat ini. Perusahaan akan mengimitasikan strategi-strategi tersebut kedalam pelaksanaan rencana bisnis ini.

Pengimitasian terhadap strategi yang akan digunakan tidak terbatas (bersumber) pada satu model ataupun satu perusahaan, tetapi dapat pula mengimitasi dengan mengkombinasikan strategi-strategi yang digunakan oleh beberapa kompetitor yang ada dan memodifikasi (apabila diperlukan) sehingga sesuai dengan kebutuhan perusahaan (Mair, 2007). Dalam hal ini yang akan diimitasi oleh perusahaan adalah kegiatan secara pada umumnya. Imitasi yang akan dilakukan mengenai bagaimana perusahaan melakukan kegiatan penjualannya, waktu penjualan. Kondisi operasional dan proses produksi perusahaan akan mengimitasi kondisi kompetitor yang sudah berjalan (Johnson, Christensen, \& Kagermann, 2008). Selain itu yang dapat dipertimbangkan adalah biaya pinjaman yang sama dengan kompetitor ataupun sedikit lebih murah, dengan mempertimbangkan kondisi yang sedang terjadi dengan penyaluran dana dan kebutuhan masyarakat.

Dalam bidang sumber daya manusia, pengimitasian dapat dilakukan pada penetapan gaji tenaga kerja, perusahaan dapat mengikuti penetapan biaya yang dilakukan oleh kompetitor, khususnya para pekerja yang berasal dari wilayah sekitar. Dengan mengimitasi dan menggabungkan dengan kemampuan internal yang sudah dimiliki, maka diharapkan dapat meminimalisir risiko sehingga perusahaan dapat 
memperoleh keuntungan yang diproyeksikan (Lieberman, 2006). Selain strategi imitasi, pada fungsi operasional perusahaan strategi yang diterapkan adalah optimalisasi kemampuan produksi dan efisiensi. Berdasarkan pada IE matrix sebelumnya, didapatkan bahwa kondisi dari perusahaan adalah Hold \& Maintain, yang berarti bahwa pada saat ini perusahaan seharusnya fokus dan penetrasi pasar. Dengan dasar inilah perusahaan akan menjalankan usahanya. Dengan demikian maka strategi yang akan dilakukan mencakup strategi imitasi yang mengedepankan prinsip fokus, optimalisasi dan efisien untuk melakukan penetrasi pasar. Berdasarkan semua strategi yang disebutkan, perusahaan akan membuat program-program sesuai dengan fungsi-fungsi yang ada dalam perusahaan.

Kegiatan awal yang harus dilakukan oleh perusahaan adalah dengan memulai kegiatan persiapan pendirian perusahaan. Ketetapan kegiatan pada tahap persiapan pendirian perusahaan ini menjadi sangat menentukan karena apabila tidak sesuai dengan waktu, akan mengganggu rencana yang telah ditetapkan. Selain itu dengan berjalannya kegiatan ini berarti pengeluaran perusahaan juga sudah mulai berjalan. Ketetapan waktu pelaksanaan akan juga mempengaruhi alur kas dari perusahaan dan tujuan-tujuan finansial lainnya. Untuk tahapan pra operasi ini maka dicanangkan 3 parameter agar efektivitas dan efisiensi dari tahap ini dapat sesuai dengan tujuan perusahaan. Berikut penjabarannya:

1. Keberhasilan persiapan pendirian yang terdiri dari: perijinan lengkap, pemilihan lokasi kantor, penjajagan hubungan dengan dealer, man power terpenuhi secukupnya

2. Ketepatan waktu kegiatan-kegiatan diatas.

3. Pengeluaran dari tahapan ini sesuai dengan anggaran yang direncanakan.

Kondisi selanjutnya setelah kegiatan pra-operasi tercapai adalah terwujudnya produktivitas optimum dan stabil untuk mendapatkan nasabah. Dengan produktivitas yang stabil, perusahaan dapat melakukan prediksi secara tepat dalam menentukan berapa besar dana yang dapat disalurkan, sehingga menambah pinjaman dari perbankan bila diperlukan.

Kondisi yang kedua yang harus dicapai adalah kemampuan perusahaan untuk melakukan penetrasi pasar untuk mendapatkan pangsa pasar pembiayaan secara syariah. Dengan strategi penetrasi pasar diharapkan perusahaan mendapatkan pangsa pasar yang ada di daerah tersebut. Besarnya kebutuhan akan pembiayaan konsumsi ini menjadi peluang untuk mendapatkan pangsa pasar tersebut, hanya bagaimana mendapatkannya secara cepat agar pada awal masa berjalannya perusahaan dapat menyalurkan pinjaman sesuai dengan modal awal yang dimiliki dan agar pengeluaran yang terjadi akibat proses awal pendirian perusahaan dapat ditutupi dengan margin yang ada. Dari strategi dan visi yang dapat disimpulkan parameter keberhasilan dari strategi bisnis dari AHD Multifinance adalah: pertama, rata-rata penyaluran pinjaman sebesar Rp 25 Milyar per bulan. Kedua, memiliki 
jangkauan nasabah diseluruh Jabodetabek dan Cikampek. Ketiga, mencapai return of equity (ROE) minimal $20 \%$

\section{Strategi Fungsional}

Setelah ditentukan parameter keberhasilan, maka guna mencapai tujuan perusahaan, parameter tersebut harus diturunkan ke dalam strategi fungsional. Strategi-strategi tersebut dijabarkan ditiap-tiap fungsi dari perusahaan dibawah ini:

1. Fungsi operation. Dari fungsi operasional perusahaan, maka strategi yang ditempuh dalam operasi pembiayaan adalah dengan mengoptimalkan sumber daya yang ada dengan efisien. Agar tujuan tersebut dapat terpenuhi, maka harus dilakukan dengan memastikan bahwa sumber dana beserta harus efisien dan tenaga kerja berfungsi sesuai dengan waktu dan target yang ditentukan. Biaya dana sangat menentukan besaran pinjaman yang bisa diberikan, tenaga kerja memastikan proses operasi perusahaan berjalan lancar.

2. Fungsi pemasaran dan humas. Untuk mencapai paramater bisnis yang telah dicanangkan di atas, maka kontribusi di fungsi pemasaran adalah dua bentuk. Bentuk pertama adalah dapat melakukan kegiatan promosi dan pemasaran pada masa pendirian agar jumlah penyaluran pinjaman dapat mencapai angka yang diinginkan pada saat beroperasinya perusahaan secara penuh. Bentuk kedua adalah mengoptimalkan pelayanan untuk mendapatkan nasabah.

3. Fungsi keuangan. Kontribusi dari fungsi keuangan dapat diraih dengan melakukan strategi pembiayaan sendiri untuk pendirian dan operasional perusahaan. Ditambah lagi dengan monitoring cash flow agar tetap mengalir sesuai proyeksi. Untuk itu, perusahaan akan menerapkan kebijakan menarik dana dari investor hanya setelah mendapatkan kepastian adanya permintaan nasabah. Pada akhir tahun, perusahaan akan membagikan laba untuk keperluan perusahaan dan pemilik.

4. Fungsi Sumber Daya Manusia. Dari fungsi SDM perusahaan, maka strategi yang ditempuh adalah performance based human management. Menurut dari strategi-strategi yang ada, fungsi SDM ini juga harus dapat melakukan proses perekrutan karyawan sesuai dengan kompetensi dari warga-warga setempat. Selain proses perekrutan, dilakukan juga proses pelatihan agar mendapatkan kompetensi dan pengalaman yang sesuai dengan kebutuhan perusahaan. Warga setempat dibutuhkan untuk memastikan pembayaran pinjaman.

\section{Perencanaan Keuangan Dan Analisis Kelayakan Investasi}

Setelah dilakukan analisis produk, rencana pengelolaan SDM, penjelasan operasional dan optimalisasi strategi perusahaan, maka tahapan yang tidak kalah penting selanjutnya adalah mengkomunikasikannya dalam bahasa keuangan melalui perencanaan keuangan dan analisis kelayakan investasi. Dalam bab ini akan dijabarkan mengenai perincian biaya, perencanaan kebutuhan investasi dan 
kebutuhan modal pembiayaan, perencanaan sumber dana, proyeksi pendapatan, laba/rugi, arus kas, neraca, serta rasio keuangan selama lima tahun dan uji kelayakan investasi. Untuk merencanakan keuangan pembiayaan dimaksud diperlukan pembentukan beberapa asumsi dasar untuk melakukan proyeksi kinerja keuangan perusahaan di masa mendatang. Adapun asumsi-asumsi mendasar yang digunakan dalam rencana usaha pembiayaan ini adalah sebagai berikut:

1. Dana investasi yang digunakan untuk pendirian PT AHD multifinance syariah 15\% berasal dari para pendiri perusahaan yaitu Wisnu Julianto, Daroe Handojo dan Hari Chairul yang selanjutnya membentuk musyarakah. Sisanya sebesar $85 \%$ berasal dari equity investor.

2. Dana pembiayaan berasal dari equity investor dan perbankan syariah dengan sistem musyarakah. Dimana dana pembiayaan dari bank turun pada saat terjadi transaksi dengan konsumen. Asumsi nisbah bagi hasil Bank dibandingkan perusahaan sebesar 60 : 40 dengan menggunakan sistem revenue sharing.

3. Pembiayaan menggunakan akad Murabahah, Mudharabah dan Salam. Akan tetapi karena keterbatasan penulis sehingga proyeksi bisnis ini hanya memuat pembiayaan murabahah untuk kendaraan bermotor saja, baik roda empat maupun kendaraan bermotor roda dua.

4. Perencanaan keuangaan yang disusun merupakan proyeksi keuangan selama 5 (lima) tahun.

5. Umur ekonomis aktiva tetap terdiri dari 3 (tiga) tahun untuk perlengkapan kantor seperti komputer, 5 (lima) tahun untuk sistem aplikasi dan 8 (delapan) tahun untuk kendaraan.

6. Perusahaan menghindari aset inventory dalam bentuk barang, kecuali aset yang berasal dari sita akibat ketidakmampuan pembayaran dari konsumen dan akan langsung di lelang (jual).

7. Pendirian perusahaan pada tahun 2012 dengan perencanaan operasi juga pada tahun yang sama.

8. Adapun asumsi yang digunakan untuk menyusun proyeksi keuangan dimasa mendatang, sebagai berikut:

Tabel 3. Asumsi Proyeksi Keuangan

\begin{tabular}{lccccc}
\hline \multicolumn{1}{c}{ Indikator } & $\mathbf{2 0 1 2}$ & $\mathbf{2 0 1 3}$ & $\mathbf{2 0 1 4}$ & $\mathbf{2 0 1 5}$ & $\mathbf{2 0 1 6}$ \\
\hline Inflasi & $8,01 \%$ & $8,01 \%$ & $8,01 \%$ & $8,01 \%$ & $8,01 \%$ \\
\hline Pajak & $25 \%$ & $25 \%$ & $25 \%$ & $25 \%$ & $25 \%$ \\
\hline SBSN & $9,25 \%$ & $9,25 \%$ & $9,25 \%$ & $9,25 \%$ & $9,25 \%$ \\
\hline Country Risk & $7,3 \%$ & $7,3 \%$ & $7,3 \%$ & $7,3 \%$ & $7,3 \%$ \\
\hline NPL ADMF & $1,1 \%-1,4 \%$ & $1,1 \%-1,4 \%$ & $1,1 \%-1,4 \%$ & $1,1 \%-1,4 \%$ & $1,1 \%-1,4 \%$ \\
\hline $\begin{array}{l}\text { NPL Bank } \\
\text { (Worst Scenario) }\end{array}$ & $5 \%$ & $5 \%$ & $5 \%$ & $5 \%$ & $5 \%$ \\
\hline
\end{tabular}

Sumber: dari berbagai sumber, diolah sendiri 
a. Tingkat inflasi yang digunakan adalah rata-rata tingkat inflasi lima tahun terakhir yaitu dari tahun 2006 sampai dengan tahun 2010, yaitu sebesar 8,01\% (Bank Indonesia, 2011).

b. Tingkat pajak sesuai peraturan UU Pajak tahun 2010 sebesar $25 \%$.

c. Surat Berharga Syariah Negara 5 tahun seri IFR0003 (setelmen pada 14 Mei 2010 dan jatuh tempo pada 15 September 2015) yaitu 9,25\% (Bank Indonesia, 2010).

d. Nilai country risk Indonesia sebesar 7,3\% pada tahun 2011 sebagaimana hasil penelitian Pablo Fernandez, Javier Aguirreamalloa dan Luis Corres, 2011.

e. Non Performing Loan (NPL) dapat dijadikan salah satu acuan dalam mengcapture profil risiko dalam sektor industri multifinance ini (AG Pahlevi,2011). Untuk benchmark dalam sektor ini dapat digunakan NPL Adira Dinamika Multi Finance (ADMF) yang rata-rata sebesar 1,3-1,4\% di tahun 2010 dan 2011. Untuk September 2011, NPL-nya di level 1,4\%. Namun demikian, terdapat tren kenaikan NPL yang menandakan penurunan kualitas kredit yang harus diwaspadai. Dalam hal ini, asumsi yang digunakan menggunakan worst scenario dari standar kesehatan NPL perbankan yaitu 5\% (normal 2,7\%). Secara nature pembiayaan multifinance menyerupai perbankan namun sesuai dengan ketententuan perundang-undangan tidak diperbolehkan untuk menghimpun dana dari masyarakat. Seharusnya untuk NPL multifinance berada dibawah tingkat tersebut. Dengan menggunakan acuan terebut maka mitigasi risiko mengenai pencadangan piutang tidak tertagih perusahaan sebesar $2 \%$ dari Pembiayaan.

\section{BUSINESS PLAN}

\section{Executive Summary}

AHD multifinace syariah adalah perusahaan baru yang bergerak pada sektor industri lembaga keuangan yang didirikan pada tahun 2012 dan beroperasi pada tahun yang sama. Dengan tujuan memberikan penyaluran kredit dalam bentuk akad syariah kepada masyarakat dan juga untuk meng-capture peluang yang ada dimana perkembangan ekonomi Indonesia yang sangat baik sehingga terciptanya pangsa pasar yang cukup luas untuk kredit kendaraan bermotor, hai ini dapat diindikasikan dari penjualan kendaraan bermotor baik roda empat (mobil) maupun roda dua (motor) yang mengalami pertumbuhan dari tahun ke tahun khususnya untuk wilayah Jabodetabek sebagai tempat berdirinya kantor pusat dan kantor cabang perusahaan ini untuk jangka waktu lima tahun pertama pendirian. Business plan ini hanya meyajikan aspek-aspek perencanaan keuangan dan analisa kelayakan investasi. Detail mengenai strategi dan operasional serta produk dan pemasaran disajikan dalam business plan lain yang dituliskan oleh Daroe Handojo (2012) dan Hari Cahirul (2012). Ketiga business plan merupakan satu kesatuan dari business 
plan lengkap AHD multifinnace syariah. Yang diatwarkan AHD Multifinance kepada pelanggannya adalah:

1. Value Proposition. AHD Multifinance menawarkan produk pembiayaan kendaraan bermotor dengan kelebihan-kelebihan, antara lain: sesuai prinsip syariah, kecepatan proses approval pembiayaan, dan pricing yang kompetitif.

2. Customer Relationship meliputi: (a) costumer criented, artinya AHD Multifinance menawarkan produk pembiayaan sesuai dan kebutuhan pelanggannya, (b) membangun kepercayaan dan loyalitas, (c) membentuk website perusahaan dan menerapkan komunikasi dengan teknologi internet sebagai jalur komunikasi antara AHD dengan konsumennya

AHD Multifinance dapat memperoleh keuntungan: pertama, cost structure meliputi (a) biaya-biaya terdiri dari biaya operasional kantor, biaya tenaga kerja, dan biaya pemasaran. (b) untuk menekan biaya, AHD melakukan efisiensi terhadap penggunaan sumber daya, seperti jumlah tenaga kerja internal, ataupun pemilihan media pemasaran yang tepat. Kedua, revenue stream yakni margin keuntungan dari pembiayaan yang disalurkan kepada pelanggan. AHD Multifinance memberikan values kepada pelanggan: pertama, core Capability yang meliputi: (a) roses pembiayaan yang cepat, (b) kepastian bahwa seluruh transaksi mengikuti prinsip syariah, terutama dengan adanya Dewan Pengawas Syariah, (c) fleksibilitas cabang dalam menentukan pricing pembiayaan, (d) memenuhi permintaan dan kebutuhan para pelanggan terkait produk pembiayaan yang dibutuhkan, (e) menerapkan teknologi informasi, dan (f) enggunaan media-media komunikasi massal seperti social media untuk mengenalkan brand dan produk AHD. Kedua, partner network meliputi : menjalin kerjasama dengan dealer-dealer kendaraan terkemuka dan bekerjasa dengan Bank Syariah, untuk mendapatkan pendanaan penyaluran pembiayaan. Ketiga, value configuration meliputi : (a) penggunaan teknologi informasi yang tepat untuk memberikan kecepatan layanan kepada pelanggan, (b) membuat website sebagai sarana komunikasi perusahaan dan pemasaran produk, (c) epatuhan syariah dan manajemen risiko yang baik untuk meminimalisir kerugian akibat munculnya risiko-risiko, (d) AHD akan menciptakan dan memanfaatkan identitas brandnya, sehingga dapat memberikan brand equity yang positif

\section{Jenis Produk Yang Ditawarkan}

Ada tiga jenis produk pembiayaan yang ditawarkan oleh AHD Multifinance kepada masyarakat: pembiayaan mobil, pembiayaan mobil niaga / truk, pembiayaan sepeda motor

\section{Skema Syariah Produk}

AHD Multifinance memilih menggunakan skema murabahah dalam produk pembiayaan dengan alasan karena murabahah memang untuk tujuan pembelian dan 
menawarkan harga (angsuran) yang tetap sampai akhir jangka waktu pembiayaan (suatu hal yang menjadi poin penarik masyarakat). Rincian skema murabahah dari AHD Multifinance dapat digambarkan sebagai berikut:

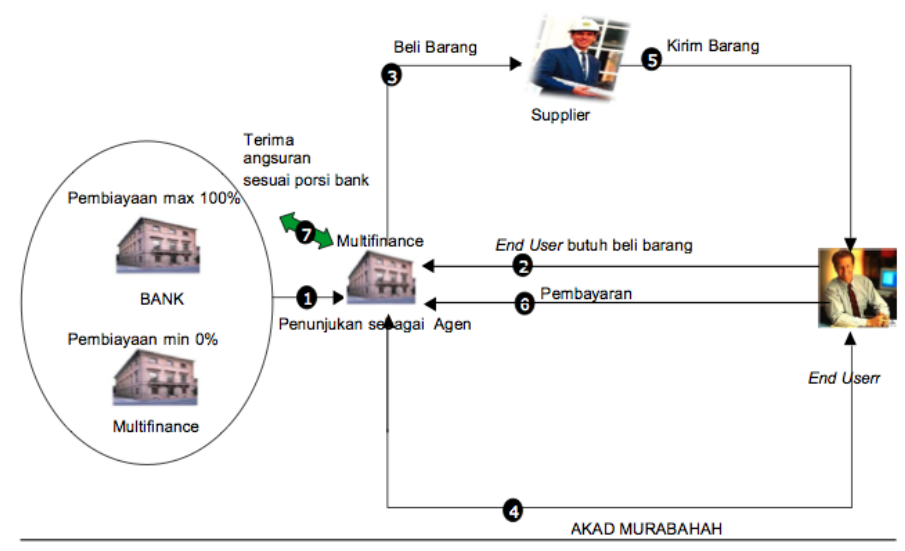

Sumber: Bank Muamalat Indonesia

Gambar 7. Skema Kerjasama AHD Multifinance dengan Bank Syariah

1. Bank menunjuk multifinance sebagai agen / mitra kerjasama dalam penyaluran pembiayaan. akad kerjasama antara bank dengan multifinance dapat menggunakan akad mudharabah maupun musyarakah tergantung pada porsi modal bank dan multifinance.

2. End user (nasabah) yang memerlukan pembiayaan kendaraan kemudian mengajukan aplikasi pembiayaan kepada multifinance. Aplikasi tersebut kemudian dianalisis oleh multifinance untuk penentuan kelayakannya. Setelah aplikasi dinilai layak, multifinance kemudian mengirimkan permohonan pencairan dana kepada bank, jika berdasarkan hasil analisis bank disetujui (sesuai dengan ketentuan dan perjanjian kerjasama), maka dapat dilakukan pencairan dana.

3. Multifinance kemudian melakukan pembelian barang kepada dealer rekanan, sekaligus melakukan pengurusan asuransi.

4. Setelah barang (kendaraan) secara prinsip dimiliki oleh multifinance, dapat dilakukan akad murabahah antara multifinance dengan nasabah, dan juga dilakukan pengikatan jaminan pembiayaan (kendaraan itu sendiri).

5. Setelah akad ditandatangani, multifinance kemudian memberikan surat permohonan kepada dealer untuk melakukan pengiriman kendaraan kepada nasabah, dan melaksanakan BAST (Berita Acara Serah Terima).

6. Setiap bulannya, nasabah melakukan pembayaran angsuran kepada multifinance sampai dengan akhir pembiayaan atau lunas. Setiap angsuran yang dibayarkan tersebut, multifinance akan mengambil pokok+margin yang menjadi haknya, dan meneruskan sisanya kepada bank (Joint Financing), atau multifinance akan mengambil margin yang mejadi haknya, dan meneruskan pokok+margin sisanya kepada bank (channeling). 


\section{Target Market}

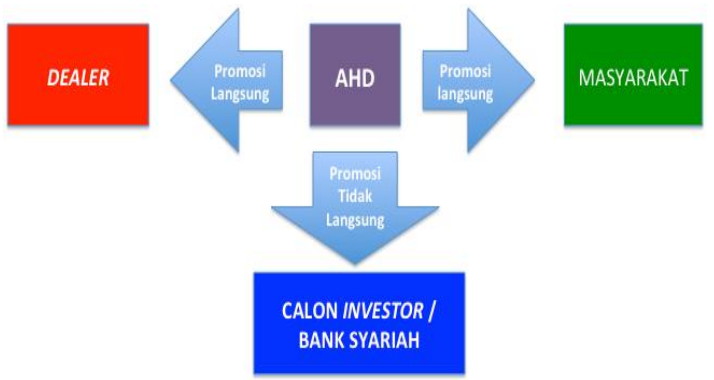

Gambar 8. Target Market AHD Multifinance

\section{Segmentasi Customer}

Tabel 4. Segmentasi Customer AHD Multifinance

\begin{tabular}{ll}
\hline Domisili & Jabodetabek \\
\hline Jenis Kelamin & Pria dan Wanita \\
\hline Usia & $21-55$ tahun \\
\hline Pekerjaan & Pegawai Negeri / Swasta, Wirausaha \\
\hline Penghasilan Per Bulan & $>5$ juta perbulan \\
\hline Agama & Mayoritas Islam \\
\hline Pendidikan & $>$ SMA \\
\hline
\end{tabular}

\section{Strategi Pemasaran}

Strategi pemasaran yang akan digunakan oleh AHD Multifinance dipilih dengan melakukan pendekatan marketing mix sebagai berikut:

1. Product. Produk AHD Multifinance adalah produk pembiayaan kendaraan syariah, dengan menawarkan keunggulan yang ada di skema murabahah, yaitu angsuran tetap. Selain itu juga memiliki keunggulan waktu approval yang cepat, dengan menggunakan sistem yang andal.

2. Price. Harga yang ditetapkan diusahakan dapat kompetitif dengan perusahaan multifinance yang sudah ada. AHD cukup mengambil margin yang tidak terlalu tinggi dari pembiayaan yang diberikan, untuk membantu masyarakat yang membutuhkan pembiayaan syariah. Selain itu setiap cabang diberikan keluasaan dalam menentukan margin pembiayaan, selama masih dalam range ketentuan dari kantor pusat. Keluasaan ini dimaksudkan untuk menyesuaikan margin dengan potensi dari masing-masing daerah dimana kantor cabang itu berada.

3. Place. Untuk meraih target pasar dan segmentasi customer yang diinginkann, maka kantor-kantor AHD Multifinance ditempatkan di daerah yang cukup strategis, yaitu dekat dengan dealer-dealer besar yang menjadi tujuan masyarakat untuk mencari kendaraan. 
4. Promotion. Untuk memasarkan produk dari AHD Multifinance ini akan dilakukan beberapa kegiatan promosi, yang secara khusus akan dibahas pada sub bab berikutnya.

Alasan pemilihan segementasi customer diatas didasarkan pada kenyataan bahwa pada masyarakat dengan kriteria tersebut, cenderung memiliki kebutuhan akan kendaraan baik mobil, kendaraan niaga (wirausaha) atau motor. Siklusnya dimulai dari saat awal bekerja (memiliki penghasilan), dimana dirasakan perlu adanya kendaraan untuk menunjang transportasi ke tempat kerja. Kemudian pada saat menikah dan memiliki anak, kebutuhan kendaraan khususnya mobil dirasa perlu. Pada saat jumlah keluarga meningkat atau promosi jabatan, kebutuhan akan lebih dari satu kendaraan muncul, dan tentunya merupakan prospek bagi perusahaan multifinance.

\section{Investasi Awal}

\section{Sumber Modal}

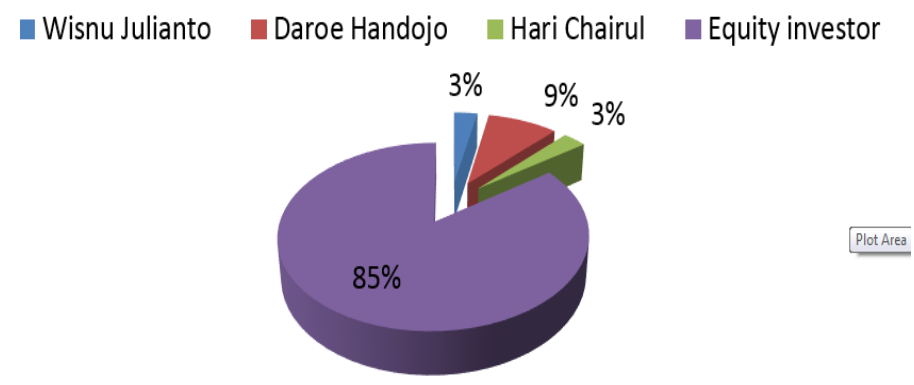

Gambar 9. Initial Investment

Investasi awal mencakup biaya pra operasi (terkait perizinan, perencanaan dan biaya lain terkait), sewa bangunan operasional, penerapan IT (dan peralatan pendukungnya), biaya utilitas, pembelian kendaraan operasional dan modal kerja dan pembiayaan dana sendiri. Kebutuhan akan pendanaan investasi berasal dari pemodal. Dengan perincian sebagai berikut:

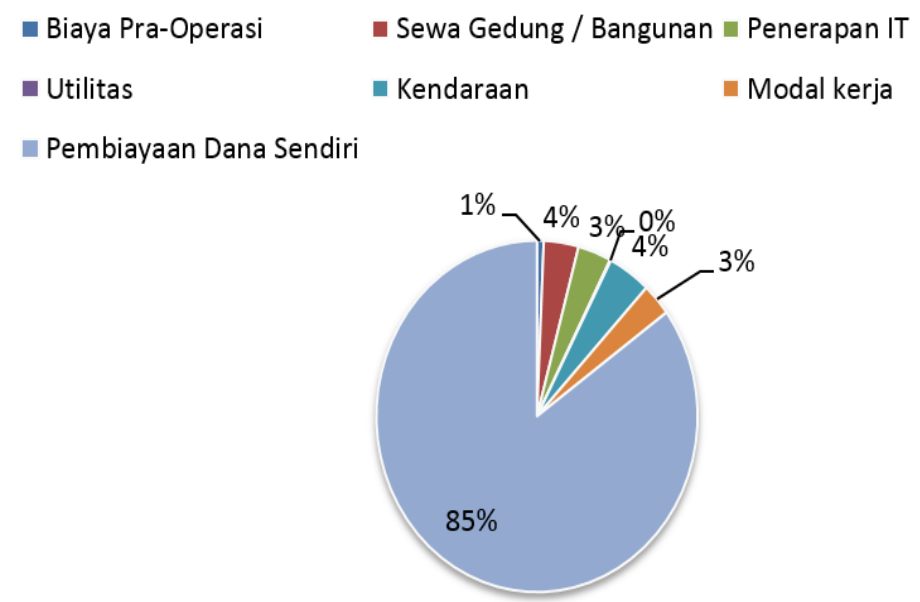

Gambar 10. Sumber Dana Initial Investment 
Tabel 5. Sumber Modal Awal Perusahaan

\begin{tabular}{lcl}
\hline $\begin{array}{l}\text { Sumber } \\
\text { Modal }\end{array}$ & $\%$ & Modal (Rp) \\
\hline Pendiri & $15 \%$ & $15,000,000,000$ \\
\hline $\begin{array}{l}\text { Equity } \\
\text { Investor }\end{array}$ & $85 \%$ & $85,000,000,000$ \\
\hline
\end{tabular}

Pendiri menyetorkan modal kepemilikan sebesar 15\% atau setara dengan Rp15 milyar, sedangkan Equity Investor menyetorkan modal sebesar $85 \%$ atau setara dengan Rp85milyar.

\section{Asumsi Penyusunan Proyeksi Keuangan}

1. Pendapatan, meliputi: (a) Pendapatan murabahah berasal dari pembiayaan kendaraan bermotor yang diasumsikan menggunakan harga kendaraan roda empat merk Toyota untuk kategori mobil penumpang dan merk Mitsubishi untuk mobil niaga. Selain itu, juga dilakukan pembiayaan untuk kendaraan roda dua, yang diasumsikan menggunakan harga motor merk Honda. Target penjualan setiap tahunnya berbanding lurus mobil dan motor sebesar 1:5. (b) Pendapatan murabahah diasumsikan sebesar 28\% dari pembiayaan untuk jangka waktu tiga tahun. Pendapatan provisi sebesar $1 \%$ dari pembiayaan dan untuk pendapatan administrasi Rp1juta untuk mobil dan Rp250ribu untuk motor. Pendapatan denda dan penalti keterlambatan akan otomatis menjadi dana kebajikan diasumsikan sebesar $0,5 \%$ dari total pembiayaan, sedangkan untuk pendapatan lain-lain diasumsikan $0,25 \%$ dari pembiayaan.

2. Beban, meliputi: (a) beban umum dan adminitrasi diasumsikan kenaikannya mengikuti proyeksi inflasi yaitu sebesar $8,1 \%$ setiap tahunnya, (b) beban penyisihan kerugian piutang sebesar $2 \%$ dari total pembiayaan, (c) beban gaji dan tunjangan untuk satu kantor pusat serta lima kantor cabang dengan jumlah karyawan sebanyak 96 orang diasumsikan naik diakibatkan inflasi dan juga kenaikan gaji sebesar 5\% pertahunnya, (d) beban perolehan pembiayaan konsumen diasumsikan sebesar $2 \%$ dari total pembiayaan, (e) beban keuangan diasumsikan sebesar $0,4 \%$ dari total pembiayaan, (f) beban pemasaran diasumsikan sebesar $0,5 \%$ dari total pembiayaan, (g) beban dana kebajikan berasal dari denda dan pinalti keterlambatan, (h) eban lain-lain diasumsikan sebesar 0,25\% dari total pembiayaan, (i), pajak Penghasilan ditentukan sebesar $25 \%$ dari laba bersih sesuai dengan kebijakan perpajakan terbaru per tahun 2010, (j) zakat keuntungan perusahaan ditetapkan 2,5\% pertahun. 


\section{Proyeksi Laba/Rugi}

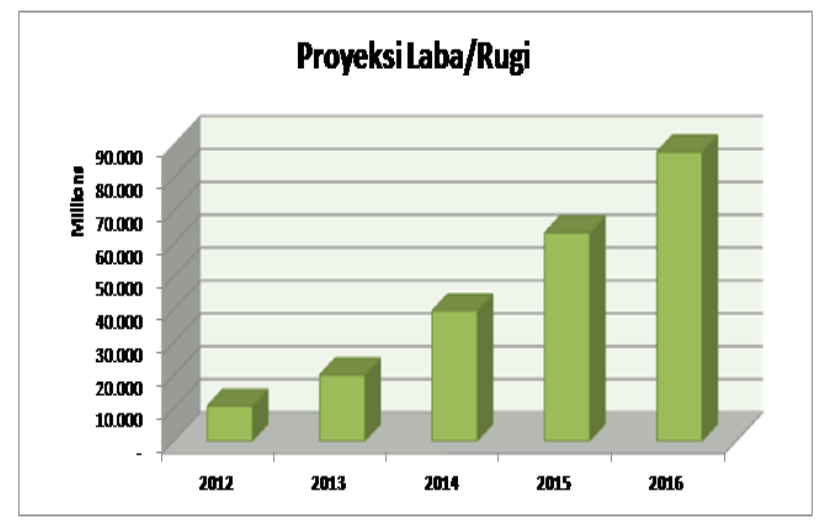

Gambar 11. Proyeksi Laba/Rugi

Setelah dilakukan proyeksi pembiayaan didapatkan pendapatan dari pembiayaan dikurangi beban operasional dan biaya bagi hasil dan tarif pajak penghasilan serta zakat. Untuk proyeksi pendapatan selama lima tahun kedepan, sejak tahun pertama telah didapatkan keuntungan yang pada tahun selanjutnya akan mengalami peningkatan.

\section{Proyeksi Neraca}

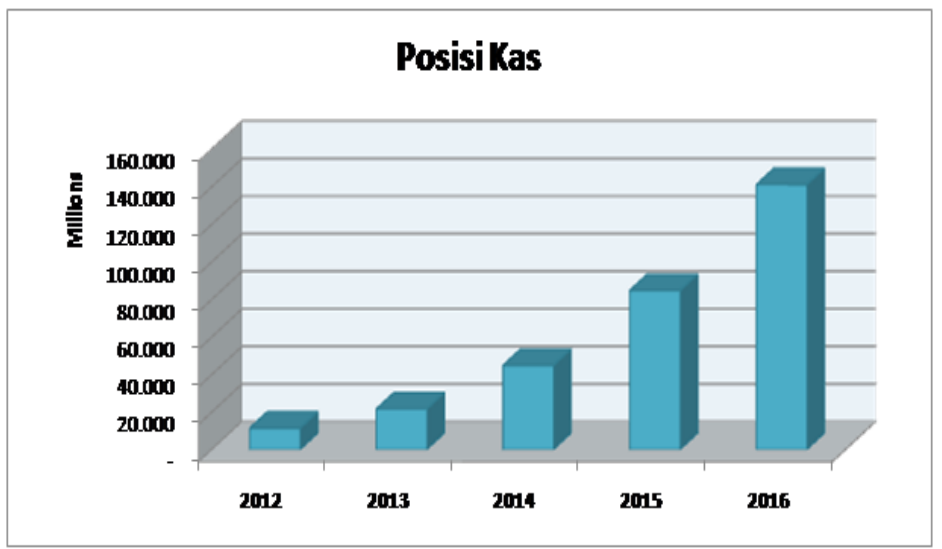

Gambar 12. Proyeksi Neraca

Proyeksi neraca (balance sheet) selama lima tahun kedepan yang sisi aktiva terdiri dari aktiva lancar (berupa kas, piutang pembiayaan murabahah konsumen dan sebagainya), aktiva tetap (aset-aset seperti properti, peralatan kantor dan kendaraan serta akumulasi deperesiasinya) dan aktiva lainnya (biaya pra operasi yang diamortisasi selama lima tahun). Selanjutnya pada sisi pasiva atau kewajiban dan modal terdapat hutang pembiayaan murabahah, modal, laba ditahan dan juga laba periode berjalan. Dari proyeksi tersebut terlihat bahwa piutang pembiayaan murabahah setiap tahun meningkat begitu pula dengan ekuitas dikarenakan deviden tidak dibagikan (laba ditahan). 


\section{Proyeksi Arus Kas}

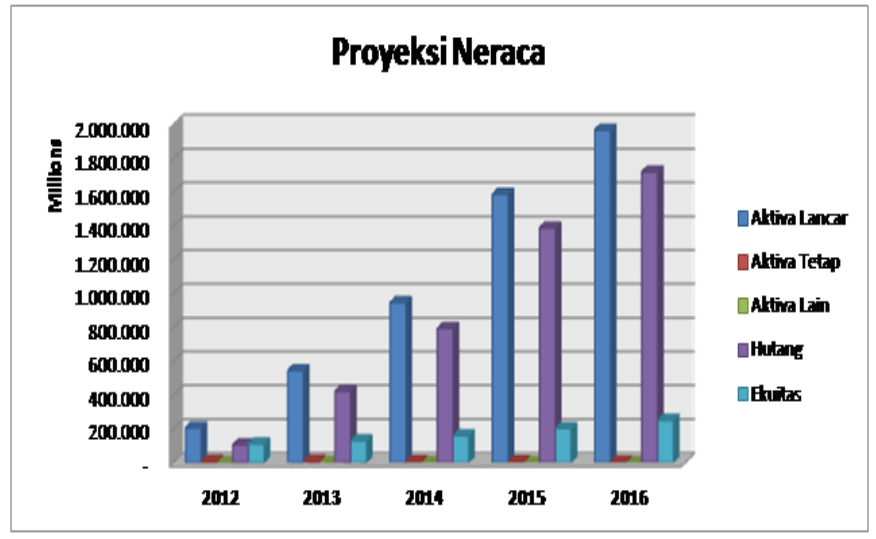

Gambar 13. Posisi Kas

1. Setoran pendanaan awal yang berasal dari pemilik dan equity investor dalam bentuk tunai.

2. Terdapat dua arus kas pembiayaan yaitu arus kas pembiyaan masuk berasal dari setoran pendanaan (modal) dana sendiri dan pembiayaan berasal dari pihak bank serta arus kas pembiayaan keluar untuk disalurkan kepada para konsumen, beban umum administrasi dan gaji tunjangan, pajak penghasilan, zakat dan pembayaran bagi hasil.

3. Dari proyeksi arus kas yang dilakukan, sejak tahun pertama arus kas bersih menunjukkan saldo positif dan pertumbuhan signifikan terlihat setelah tahun kedua beroperasi.

\section{Analisis Break-even}

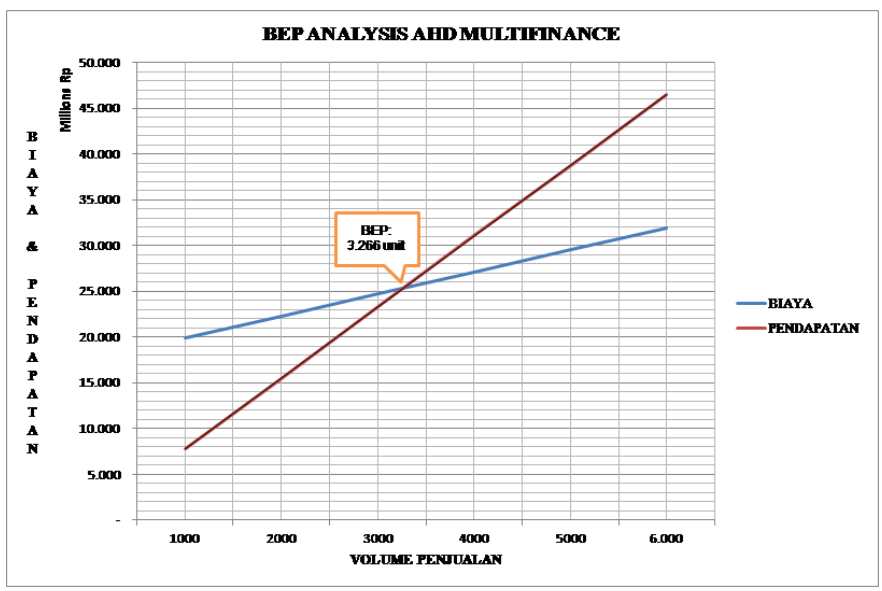

Gambar 14. Break Even Analysis

Dengan menggunakan Break Even Point Analysis, pada tahun pertama pembiayaan sudah dapat mencapai break even dengan total unit yang dibiayai sejumlah 3.266 unit, dibawah target pembiayaan yaitu 6.000 unit untuk tahun pertama. Diperoleh unit BEP untuk masing-masing kendaraan mobil dan motor sebanyak 544 unit dan 2.722 unit. 


\section{Analisis Kelayakan Investasi}

Tabel 6. Resume Perencanaan Keuangan dan Analisis Kelayakan Investasi

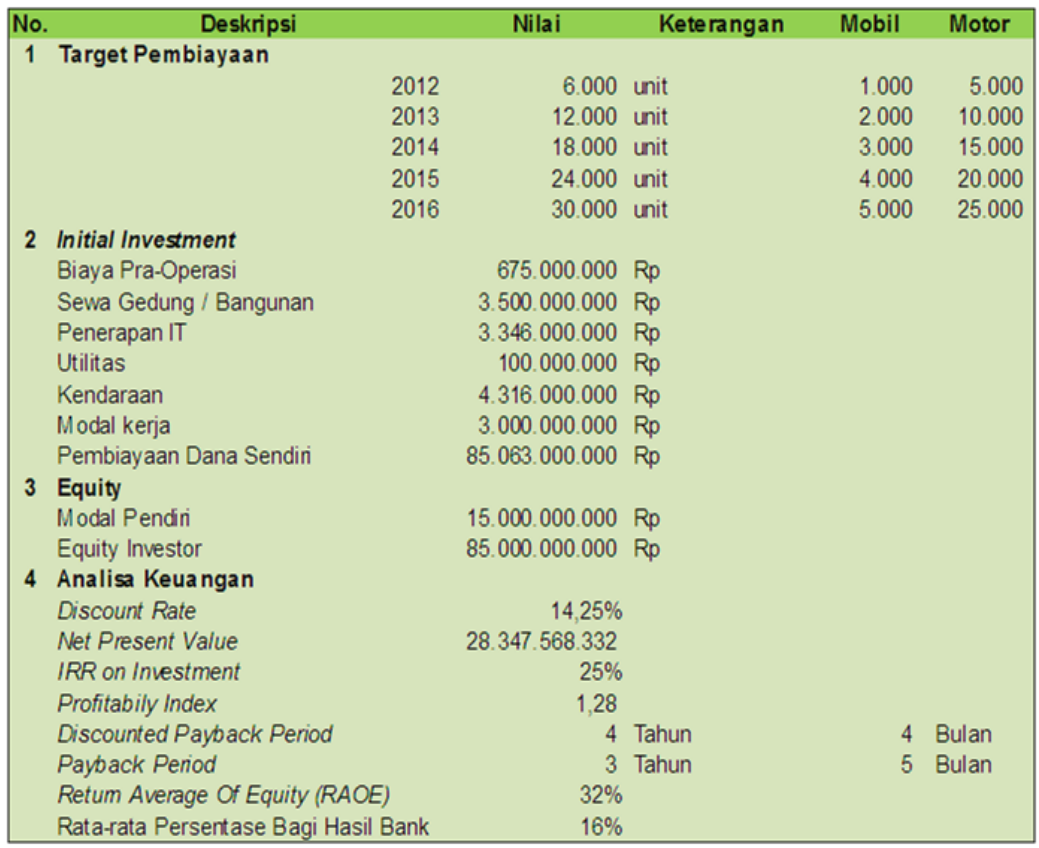

a. NPV > 0, yaitu sebesar Rp28.347.568.332,- sehingga usulan pembiayaan dapat diterima.

b. IRR $=25 \%$, nilai yang lebih besar apabila dibandingkan dengan asumsi discount rate yang digunakan yaitu sebesar 14,25\% maka investasi dapat diterima. Hal ini karena menyiratkan keuntungan dari aliran kas investasi lebih dari discount rate.

c. Tingkat Profitability Index (PI) > 1, yaitu sebesar 1,28 sehingga usulan pembiayaan dapat diterima.

d. Payback Period menunjukan 3 tahun 5 bulan apabila tidak menggunakan discount factor maka pembiayaan akan memperoleh pembayaran kembali atas investasi pada tahun ke tiga bulan ke lima (Mei 2015).

e. Discounted Payback Period menunjukan 4 tahun 4 bulan bahwa pembiayaan akan memperoleh pembayaran kembali atas investasi pada tahun ke empat bulan ke empat (bulan April 2016).

\section{SIMPULAN}

Proyek pembiayaan syariah dengan konsep bagi hasil yang berlandaskan prinsip ekonomi Islam dapat menjadi solusi ditengah keterpurukan perekonomian dunia akibat penerapan ekonomi konvensional berbasis riba yang bersifat spekulatif dan eksploitatif. Multifinance syariah dapat berkontribusi dalam pengembangan ekonomi Islam untuk mencapai kemaslahatan masyarakat melalui penyaluran dana kepada sektor riil dengan aturan yang lebih fleksibel dari pada perbankan. Ditinjau dari sisi pasar, perekonomian di Indonesia dapat berpengaruh positif terhadap perkembangan multifinane syariah ini karena pertumbuhan ekonomi Indonesia 
cenderung positif ditengah krisis yang melanda dunia barat. Hal ini tercermin dalam tren daya beli dan pendapatan masyarakat yang meningkat. Dilihat dari aspek sosial, politik dan teknologi terdapat tantangan dimasa depan yang diharapkan tidak sampai mengganggu stabilitas perekonomian Indonesia. Sedangkan bila dievaluasi dari tren lingkungan industri, industri multifinance syariah semakin menarik bagi banyak investor dan pemain. Secara umum, berdasarkan analisis pasar yang telah dilakukan, usaha pembiayaan syariah ini meskipun memiliki banyak tantangan tetapi dapat sangat menguntungkan.

Potensi pengembangan industri multifinance syariah terbuka lebar dan hal ini harus diantisipasi perusahaan dengan peningkatan mutu SDM, pemilihan strategi yang efektif dan pengembangan jaringan usaha atau ekspansi yang memadai. Berdasarkan analisa industri dengan metode EFE dan IFE serta analisa SWOT Perusahaan akan menggunakan strategi yang bersifat fokus terhadap pasar dengan menjalin dan membangun hubungan yang baik kepada stakeholder terkait. Perusahaan akan mengimitasi strategi usaha competitor yang disesuaikan dengan kondisi dan kebutuhan perusahaan mengingat perusahaan merupakan pemain baru dalam industri ini, dalam hal kegiatan dan waktu penjualan, proses operasional, pengelolaan SDM serta biaya pinjaman yang disesuaikan agar atraktif untuk pangsa pasar. Investasi pembiayaan PT AHD multifinance syariah ini memiliki prospek keuangan yang menguntungkan sehingga layak untuk dibiayai. Setelah dilakukan proyeksi keuangan dan analisis kelayakan investasi, perencanaan bisnis ini layak untuk dijalankan. Dengan perolehan IRR sebesar $25 \%$ berpotensi meningkatkan kesejahteraan stakeholder, terutama para pemilik modal. Dengan mempertimbangkan tiga skenario jumlah unit pembiayaan, dimana dalam skenario pesimis menghasilkan NPV yang negatif, IRR dibawah tingkat diskonto dan PI kurang dari 1, sehingga diperlukan strategi-strategi untuk meningkatkan unit pembiayaan agar target pembiayaan selama jangka waktu lima tahun dapat terealisasi.

Analisa dan proyeksi merupakan perencanaan atau perkiraan yang dapat berubah seiring dengan adanya perubahan pada variabel asumsi. Hal ini dapat berdampak kepada manajemen, operasional dan keuangan perusahaan. Untuk itu, timbul tuntutan terhadap manajemen perusahaan untuk dapat flexible atau menyesuaikan diri apabila perencanaan tidak sesuai dengan kondisi yang ada. Adapun perencanaan tetap dibutuhkan sebagai pedoman dan tolak ukur kinerja serta pencapaian perusahaan. Fungsi pemantauan dan evaluasi (controlling) dari manajemen harus diimplementasikan untuk mengidentifikasi risiko yang dihadapi serta alternatif solusi untuk memitigasi risiko dimaksud. Beberapa risiko yang dapat diidentifikasi adalah sebagai berikut: pertama, adanya wacana pematokan uang muka multifinance sebesar 30\% dari intervensi Bank Indonesia dapat berdampak selain membawa sentimen negatif terhadap nilai saham perusahaan multifinance 
(short term) juga berpengaruh terhadap laju pertumbuhan kredit terutama untuk konsumtif pembiayaan kendaraan bermotor. Meskipun hal ini dapat membawa pengaruh positif terhadap profil risiko industri multifinance untuk jangka waktu panjang. Kedua, situasi krisis yang melanda AS dan kawasan Eropa saat ini masih belum menunjukkan tanda-tanda pemulihan. Meskipun Indonesia tidak terkena dampaknya secara signifikan namun demikian situasi ini meningkatkan ketidakpastian (uncertainty) yang dapat berdampak pada variabel atau indikator ekonomi sehingga mempengaruhi estimasi-estimasi yang telah dibuat. Ketiga, Gejolak perekonomian dan situasi politik menjelang pemilu pada tahun 2014 dapat menimbulkan ketidakpastian akan pencapaian operasional dan kinerja keuangan perusahaan. Keempat. asumsi untuk menilai kinerja keuangan berubah seiring dengan perubahan lingkungan industri dan kondisi remote environment yang dapat menguntungkan ataupun merugikan bagi perusahaan. Hal ini akan berdampak pada tidak relevannya tolak ukur atau target yang telah ditetapkan diawal apabila asumsi berubah secara signifikan. Untuk itu, perusahaan harus melakukan pemantauan dan evaluasi terhadap berbagai asumsi yang digunakan. Dalam hal terdapat perubahan yang signifikan maka perusahaan harus melakukan penyesuaian yang dibutuhkan.

\section{DAFTAR PUSTAKA}

Damanik, H. C. (2012). Business Plan Project: Pendirian AHD Multifinance Syariah sebagai Upaya Peningkatan Pembiayaan dengan Skema Syariah: Telaah Aspek Produk dan Pemasaran. Jakarta: Universitas Indonesia.

Daft, M. (2006). Understanding Management. $5^{\text {th }}$ ed. Thomson South-Western.

David, F. R. (2003). Strategic Management: Concepts and Cases. $9^{\text {th }}$ ed. New Jersey: Prentice Hall.

Fernandez, P., Aguirreamalloa, J. \& Corres, L. Market Risk Premium used in 56 Countries in 2011: A Survey with 6,014 Answers. IESE Business School: University of Navarra.

Grant, R. M. (2004). Contemporary Strategy Analysist: Concept, Technique, Application. $4^{\text {th }}$ ed. Massachusetts: Blackwell.

Handojo, D. (2012). Business Plan Project: Pendirian AHD Multifinance Syariah sebagai Upaya Peningkatan Pembiayaan dengan Skema Syariah: Telaah Aspek Strategi Bisnis dan Operasional. Jakarta: Universitas Indonesia.

Henderson, B. D. (1989). The Origin of Strategy. Harvard Business Review. 139-43.

Hill, C. W. L., \& Jones G. R. (2008). Strategic Management. $8^{\text {th }}$ ed. Boston: Houghton Mifflin.

Ireland, R. D., Hoskisson, R. E. And Hitt, M. A. (2007). The Management of Strategy Concepts and Cases. $8^{\text {th }}$ ed. South-Western Cengage Learning.

Johnson, M. W., Christensen, C. M., \& Kagermann, H. (2008). Reinventing Your Business Model. Harvard Business Review: 1-11. 


\section{Islãmadîna}

Karim, A. A. (2007). Ekonomi Mikro Islami. Jakarta: PT. RajaGrafindo Persada.

Lieberman, M. B. (2006). Why do firm imitate each other. Academy of Management Review, Vol. 31, No. 2, 366-385.

Mair, J. \& Schoen O. (2007). Succesful social entrepreneurial business models in the context of developing economies. International Journal of Emerging Markets, Vol. 2, No. 1, 54-68.

Ohmae, K. (2005). The next global stage: challenges and opportunities in our borderless world. Pearson Prentice Hall.

Porter, M. E. (2008). The Five Competitive Forces That Shape Strategy. Harvard Business Review.

.. (2011). Data Strategis BPS. Jakarta: Badan Pusat Statistik.

.. (2011). Ketetapan Hasil Lelang Surat Berharga Syariah Negara Atau Sukuk Negara Seri IFR0003 (Reopening), IFR0005 (New Issuance), IFR0006 (New Issuance) Dan IFR0007 (New Issuance) 19 Januari 2010. Jakarta: Bank Indonesia. . (2011). Laporan Inflasi: Januari 2006 - Desember 2010

Fatwa Dewan Syari'ah Nasional No. 04/DSN-MUI/IV/2000 tentang Murabahah. Majelis Ulama Indonesia

Fatwa Dewan Syari'ah Nasional No. 08/DSN-MUI/IV/2000 tentang Pembiayaan Musyarakah. Majelis Ulama Indonesia

Fatwa Dewan Syari'ah Nasional No. 62/DSN-MUI/XII/2007 tentang Akad Ju'ala

h. Majelis Ulama Indonesia 